\title{
Assessment of methyl methacrylate vapor toxicity on the rat tracheal epithelium
}

\section{Análise da toxicidade dos vapores de metil metacrilato sobre 0 epitélio traqueal de ratos}

\author{
José Luiz Santos Parizi* \\ Gisele Alborghetti Nai* \\ Camila Fedatto Batalha** \\ Carla Cristina Barbosa Lopes*** \\ Mariana Fernandez Rizzo** \\ Ciro Eduardo Falcone*** \\ José Maria Bertão*
}

\begin{abstract}
Methyl methacrylate (MMA) is a monomer that is polymerized into resin by light and heat, producing a clear, resistant, durable and relatively inert plastic material. Because of these characteristics, MMA is largely used in Medicine as bone cement and in Dentistry, in dental braces and prostheses, thus generating continuous interest in its toxicity. Experimental and clinical studies have documented that monomers may cause a wide range of adverse health effects. The most important occupational exposure route of MMA is by inhalation. This study aims to evaluate the toxicity of MMA to the tracheal epithelium, according to the time of exposure. For this purpose, two experimental groups of rats were exposed to MMA by inhalation under poor ventilation: one group $(n=36)$ was exposed permanently, and the other $(n=36)$ was exposed during 8 hours per day, without water and food supply during the exposure period. A control group $(n=8)$ received normal air supply. Twelve animals of each study group were sacrificed after 5, 8 and 10 days of exposure together with two or four control animals. Twenty-nine $(80.5 \%)$ of the rats continuously exposed to MMA developed inflammation on the tracheal epithelium, as well as $58.33 \%$ $(\mathrm{n}=21)$ of those exposed $8 \mathrm{~h} /$ day and $87.5 \%(n=7)$ of the control rats. No association was observed between the inflammatory process and MMA exposure; no significant alterations in the tracheal epithelium thickness were observed. Further studies on longer exposure times and analysis of other parameters will have to be conducted to exclude the possibility of tracheal damage by vapors of MMA.
\end{abstract}

DESCRIPTORS: Methylmethacrylate; Trachea; Toxicity.

\begin{abstract}
RESUMO: O metil metacrilato (MMA) é um monômero que se polimeriza em resina pela ação da luz e do calor, transformando-se em plástico claro, resistente e durável, relativamente inerte. Por apresentar tais características, o MMA tem sido muito usado na Medicina, como cimento ósseo, e na Odontologia, em aparelhos e próteses dentais, o que tem suscitado interesse na avaliação de sua toxicidade. Estudos experimentais e clínicos têm mostrado que os monômeros podem causar uma gama de efeitos adversos. A principal via de exposição ocupacional ao MMA é a inalatória. Este trabalho visa a avaliar a ação tóxica do MMA sobre o epitélio traqueal em relação ao tempo de exposição. Para isso, dois grupos experimentais de ratos foram expostos ao MMA por inalação, com restrição de ventilação: um grupo $(\mathrm{n}=36)$ foi exposto continuamente, e outro $(\mathrm{n}=36)$ foi exposto durante oito horas diárias, sem água e comida durante o período de exposição. Um grupo controle $(n=8)$ recebeu ar normal. Doze animais de cada grupo de estudo foram sacrificados com 5, 8 e 10 dias de exposição, junto com dois ou quatro animais do grupo controle. Vinte e nove $(80,5 \%)$ dos ratos expostos continuamente ao MMA apresentaram inflamação do epitélio traqueal, assim como $58,33 \%(n=21)$ daqueles expostos 8 horas/dia e $87,5 \%(n=7)$ dos controles. Não se observou associação entre o processo inflamatório e a exposição ao MMA, nem alterações significativas na medida da espessura do epitélio traqueal. Novos estudos, com tempo mais prolongado de exposição e análise de outros parâmetros, devem ser realizados para que seja excluída, totalmente, a possibilidade de dano traqueal por vapores de MMA.
\end{abstract}

DESCRITORES: Metilmetacrilato; Traquéia; Toxicidade.

\section{INTRODUCTION}

Methyl methacrylate (MMA) has been used over the last 50 years for acrylic resin production and has a wide range of application in plastics and the building industry, as well as in Medicine and Dentistry ${ }^{11}$.

\footnotetext{
*Professors, Department of Pathology; **Dental Surgeons, School of Dentistry; ***Students, School of Medicine - Western São Paulo State University.
} 
Parizi JLS, Nai GA, Batalha CF, Lopes CCB, Rizzo MF, Falcone CE, Bertão JM. Assessment of methyl methacrylate vapor toxicity on the rat tracheal epithelium. Braz Oral Res 2005;19(3):223-7.

Acrylic polymers were introduced into Dentistry in 1937, and by 1946 it was estimated that $98 \%$ of the dental materials were made of $\mathrm{MMA}^{9}$.

Deichmann $^{4}$ (1941) was the first to have a study about the environmental damages caused by MMA published and to test some of its administration routes (oral, subcutaneous, inhalational and cutaneous).

In Medicine and Dentistry, the main professional exposure route is inhalation ${ }^{1}$; the Occupational Safety and Health Code established the average of 8 hours permissible to MMA exposure at $100 \mathrm{ppm}^{2}$; exposure at higher levels can generally cause injuries from local ocular and mucosal irritation, including stomatitis, to asthma and systemic effects such as neurologic disturbances $5,8,12,16,22$.

The toxicity of MMA to patients has been largely studied. However, not many studies have been conducted to demonstrate its potential hazardous property to persons exposed to its vapor, especially technicians who work in prosthesis production facilities ${ }^{13,14}$.

As MMA is largely used in dental prosthesis production and due to its great volatility, this study was delineated to investigate its potential toxic action on the tracheal epithelium and its relationship to the time of exposure.

\section{MATERIAL AND METHODS}

We selected 80 Wistar albino rats aged 90 days, 40 males and 40 females, which were grouped in a number of three per cage and put in different shelves in a place controlled for temperature and humidity and equipped with 12-hour dark-light cycle.

The animals were divided into three groups: one group continuously exposed to MMA ( $\mathrm{n}=36)$, a group exposed to MMA for 8 hours per day without water and food intake $(\mathrm{n}=36)$, and a control group $(n=8)$, which was kept in a separate place.

The plastic boxes in which rats were placed had an upper grate covered by a piece of white non recycled plastic over three quarters of its surface (ventilation restricted). Amber flasks (Nadir Figueiredo Indústria e Comércio, São Paulo, Brazil) of $100 \mathrm{ml}$ capacity and having a 2-cm-diameter opening with perforated cover were supplied with $10 \mathrm{ml}$ of MMA (99.9\% obtained from CLÁSSICO Brazilian Industry Limited, São Paulo, Brazil) and placed in each box, fixed to the grate.

After 5 and 8 days of exposure, 12 rats $(6$ males and 6 females) of each group were sacrificed together with two control animals. After 10 days of exposure, 12 rats of each group and four controls were sacrificed.

Sacrifice was carried out with $2 \mathrm{ml}$ of thiopental (Abbott Laboratories, Chicago, USA) administered in the peritoneal cavity and necropsy was performed. An annular fragment from the medium third of the trachea was extracted.

The material collected was routinely processed, fixed in 10\% formalin (Cinética Indústria Química, São Paulo, Brazil) during 24 hours, embedded in paraffin (Dinâmica Reagentes Analíticos, São Paulo, Brazil), sectioned (in sections of $5 \mu \mathrm{m}$ ), and stained with Hematoxylin and Eosin (H\&E) (Dolles, São Paulo, Brazil).

Measurements of the tracheal epithelium thickness were carried out in four areas of each fragment using an image analysis system (IMAGELAB 2000, supplied by the University of São Paulo, Brazil) (Figure 1).

Statistical analysis was conducted by means of analysis of variance, and two factors (exposure procedure and sacrifice period) were considered. Gender was related to the thickness of the tracheal epithelium. For the categoric variable, tracheal inflammation, the chi-squared test was performed for the independent samples in order to check its association with exposure procedure, sacrifice period and gender.

\section{RESULTS}

\section{Histopathological analysis of the trachea}

An inflammatory process in the submucosa predominantly composed of lymphocytes with rare plasma cells and neutrophils was observed (Figure 2).

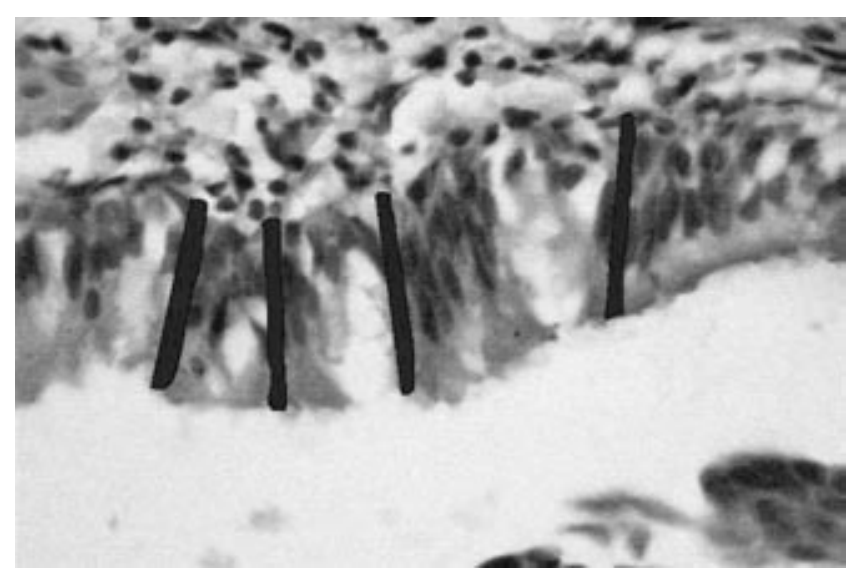

FIGURE 1 - Measurement pattern of tracheal epithelium thickness - control female rat (IMAGELAB - Hematoxylin - Eosin, $40 \mathrm{X}$ ). 
Parizi JLS, Nai GA, Batalha CF, Lopes CCB, Rizzo MF, Falcone CE, Bertão JM. Assessment of methyl methacrylate vapor toxicity on the rat tracheal epithelium. Braz Oral Res 2005;19(3):223-7.

Among the rats continuously exposed to MMA, $80.5 \%(\mathrm{n}=29)$ had tracheal epithelium inflammation. So did $58.33 \%(n=21)$ of the $8 \mathrm{~h} /$ day exposure group, and $87.5 \%(\mathrm{n}=7)$ of the control animals (Table 1). An inflammatory process was observed in seventeen $(65.38 \%)$ of them after 5 days of exposure (Table 2).

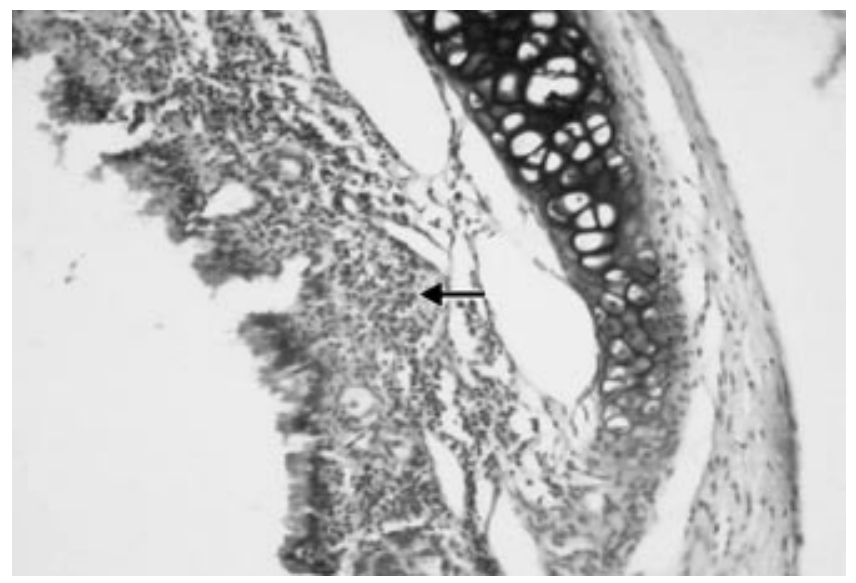

FIGURE 2 - Photomicrograph of trachea showing chronic inflammation of the submucosa (arrow) - 5 days of continuous exposure, male rat (Hematoxylin - Eosin, $10 \mathrm{X})$.

TABLE 2 - Relation (number of rats) between tracheal inflammation and sacrifice period.

\begin{tabular}{c|c|c|c}
\hline \hline \multirow{2}{*}{ Sacrifice period } & \multicolumn{3}{|c}{ Tracheal inflammation } \\
\cline { 2 - 4 } & Present & Absent & Total \\
\hline 5 days & 17 & 9 & 26 \\
\hline 8 days & 20 & 6 & 26 \\
\hline 10 days & 20 & 8 & 28 \\
\hline Total & 57 & 23 & 80 \\
\hline \hline
\end{tabular}

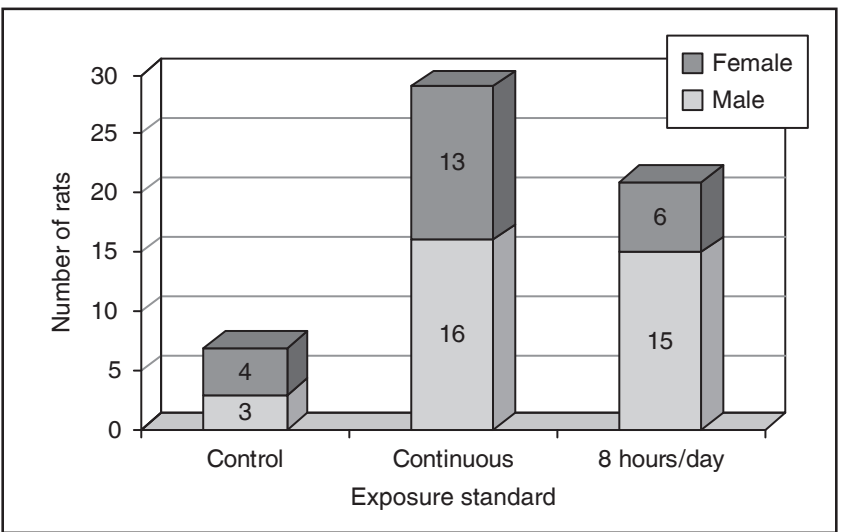

GRAPH 1 - Distribution of rats with tracheal inflammation according to exposure type and gender $(\mathrm{n}=57)$.
Thirty-four $(85 \%)$ of the male rats and only $23(57.5 \%)$ of the female rats had tracheal inflammation (Table 3 - Graphs 1 and 2). A significant association between sex and presence of tracheal inflammation ( $\mathrm{p}=0.007)$ was observed, but not between gender and type of exposure $(p=0.064)$ and between gender and sacrifice period $(p=0.655)$.

\section{Thickness measurement of tracheal epithelium}

Due to technical difficulties, 3 cases were excluded from this analysis: 2 female controls and one female rat exposed to MMA for 8 hours/day.

There were no significant differences for this parameter among the different groups $(p>0.05)$ (Graph 3).

TABLE 1 - Relation (number of rats) between tracheal inflammation and exposure type.

\begin{tabular}{c|c|c|c}
\hline \hline \multirow{2}{*}{ Exposure type } & \multicolumn{3}{|c}{ Tracheal inflammation } \\
\cline { 2 - 4 } & Present & Absent & Total \\
\hline Control & 7 & 1 & 8 \\
\hline Continuous & 29 & 7 & 36 \\
\hline 8 hours/day & 21 & 15 & 36 \\
\hline Total & 57 & 23 & 80 \\
\hline \hline
\end{tabular}

TABLE 3 - Relation (number of rats) between tracheal inflammation and gender of animals.

\begin{tabular}{c|c|c|c}
\hline \hline \multirow{2}{*}{ Gender } & \multicolumn{3}{|c}{ Tracheal inflammation } \\
\cline { 2 - 4 } & Present & Absent & Total \\
\hline Male & 34 & 6 & 40 \\
\hline Female & 23 & 17 & 40 \\
\hline Total & 57 & 23 & 80 \\
\hline \hline
\end{tabular}

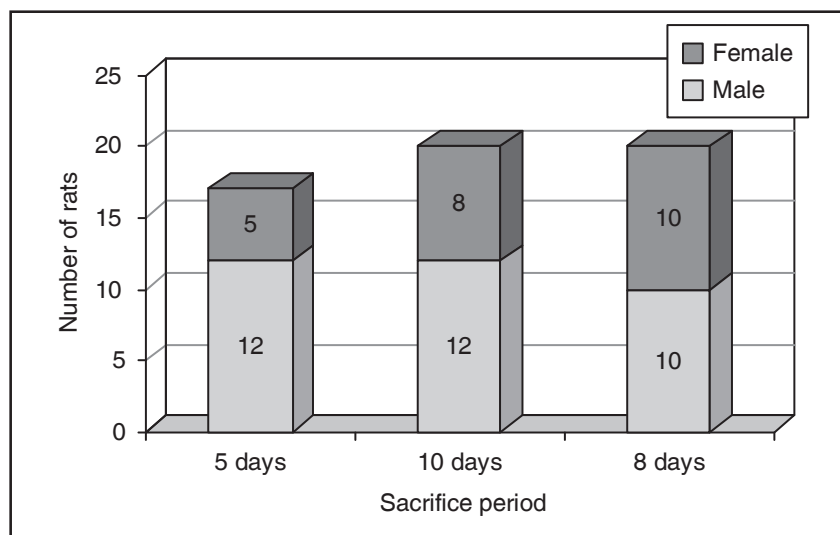

GRAPH 2 - Distribution of rats with tracheal inflammation according to sacrifice period and gender $(\mathrm{n}=57)$. 
Parizi JLS, Nai GA, Batalha CF, Lopes CCB, Rizzo MF, Falcone CE, Bertão JM. Assessment of methyl methacrylate vapor toxicity on the rat tracheal epithelium. Braz Oral Res 2005;19(3):223-7.

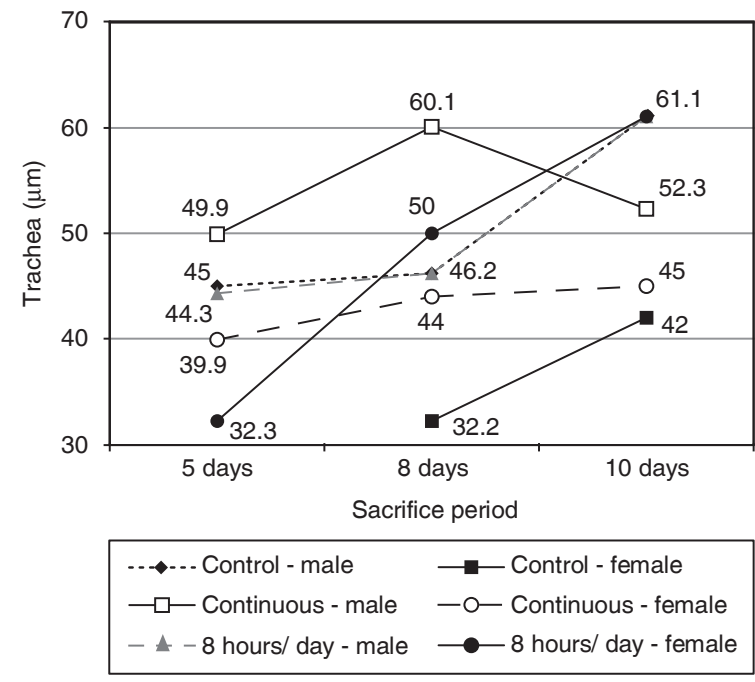

GRAPH 3 - Variation of the tracheal epithelium thickness in rats related to exposure type and sacrifice period and classified per gender $(\mathrm{n}=77)$.

\section{DISCUSSION}

MMA derives from methacrylic acid. It has the structural formula observed in Figure 3 and a molecular weight of 100 , specific gravity of 0.936 , boiling point of $100-101^{\circ} \mathrm{C}$ and refraction index of 1.413 at $20^{\circ} \mathrm{C}^{4}$.

It is transformed into resin by light, heat, oxygen and oxygenated compounds, and has great applicability at this polymerized state ${ }^{1,9}$. Acrylic products resulting from this polymerization and in accordance with recommended technical rules do not cause tissue damage and are of low toxicity to patients ${ }^{9}$.

Due to its volatility, occupational exposure occurs by inhalational route, being first hydrolyzed in the nasal cavity by the carboxylesterase enzyme $^{13,18}$.

The exposure of prosthetic laboratory workers to these monomers has been studied in the last decades, but few studies have been conducted to evaluate the potential damage of MMA on several tissues. It has been reported that MMA is not carcinogenic $^{11,18}$ or teratogenic ${ }^{19}$.

Many studies that evaluate damage to the respiratory tract, specially to the nasal cavity, report inflammation, glandular atrophy, focal hyperplasia of basal cells and squamous metaplasia of the nasal cavity epithelium ${ }^{1,11,13}$.

MMA effects on olfactory tissue show a pattern of regeneration during continuous exposure

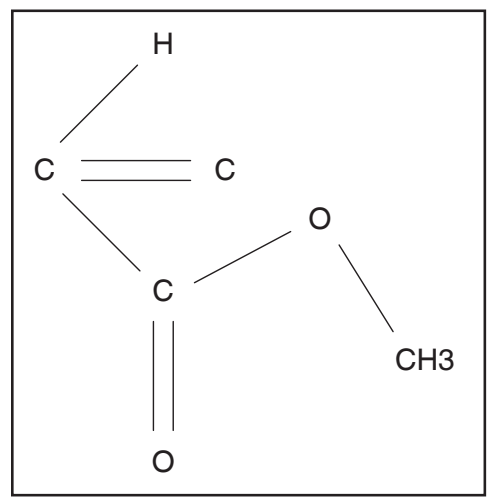

FIGURE 3 - Structural formula of methyl methacrylate. and degeneration that originates disorganization and an apparent resolution ${ }^{7}$, also noticeable in exposure to other chemical agents ${ }^{6,10}$.

Only Tansy et al. ${ }^{20,21}(1980,1979)$ studied injuries to the tracheal epithelium. Using light microscopy, they noticed only isolated hemorrhagic foci, but when submitting these areas to electron microscopy evaluation, they detected ciliary denudation and reduction in the number of microvilli.

In our study, we observed a predominantly lymphocytic mixed inflammatory infiltrate in the tracheal epithelium of exposed and control rats. This finding is not statistically significant concerning the analysis of inflammation and MMA exposure. The predominance of the inflammatory process in male rats, regardless of the exposure to MMA, is of statistical significance.

Tracheal epithelium thickness of MMA exposed rats proved similar to that of control rats, and cell adaptations such as atrophy and hypertrophy were not observed.

Although not experimentally demonstrated, it is believed that the toxicity of MMA to the respiratory tract mucosa is the result of a high activity of carboxylesterase enzymes and consequent formation of methacrylic acid, an irritant and chemical corrosive $^{13}$.

Toxic injury associated with MMA vapors could at least be partially related to metabolites originated from carboxylesterase enzyme degradation, and not only to its direct action over tissues as demonstrated for ethyl acrylate toxicity ${ }^{15}$.

Carboxylesterase enzyme can be found in higher concentrations in the olfactory epithelium and in lower concentrations in the respiratory epithelium $^{3,17}$, which could possibly justify the absence of damage to the respiratory-type tracheal epithelium.

In 2001, Mainwaring et al. ${ }^{13}$ published a comparative study on the action of MMA in the nasal 
Parizi JLS, Nai GA, Batalha CF, Lopes CCB, Rizzo MF, Falcone CE, Bertão JM. Assessment of methyl methacrylate vapor toxicity on the rat tracheal epithelium. Braz Oral Res 2005;19(3):223-7.

epithelium of rats, hamsters and humans. They concluded that the latter were less susceptible to the toxic action of MMA than the former two.

Differences in nasal morphology between rats and humans and in the metabolism of MMA, such as a lower carboxylesterase enzyme activity in humans, suggest that humans might develop toxic lesions related to MMA exposure vapors in lower extent ${ }^{13}$. This has to be taken into account, since the findings of experimental studies with rats cannot be reliably considered for human beings.

The present study corroborates the findings of Tansy et al. ${ }^{20,21}(1980,1979)$, who have shown that the damage to the tracheal epithelium could possibly be restricted to the cell microstructure and

\section{REFERENCES}

1. Aydin O, Attila G, Dogan A, Aydin MV, Canacankatan N, Kanik A. The effects of methyl methacrylate on nasal cavity, lung, and antioxidant system (an experimental inhalation study). Toxicol Pathol 2002;30(3):350-6.

2. Barash PG. Preparação para a anestesia. In: Manual de anestesiologia clínica. São Paulo: Manole; 1991. p. 45.

3. Bogdanffy MF, Randall HW, Morgan KT. Biochemical quantitation and histochemical localization of carboxylesterase in the nasal passages of the Fischer-344 rat and B6C3F1 mouse. Toxicol Appl Pharmacol 1987;88:183-94.

4. Deichmann W. Toxicity of methyl, ethyl and butyl methacrylate. J Ind Hyg Toxicol 1941;23(7):343-51.

5. Donaghy M, Rushworth G, Jacobs JM. Generalized peripheral neuropathy in a dental technician exposed to methyl methacrylate monomer. Neurology 1991;41:1112-6.

6. Gaskell BA, Hext PM, Pigott GH, Hodge MC, Tinston DJ. Olfactory and hepatic changes following inhalation of 3-trifluoromethyl pyridine in rats. Toxicology 1988;50:57-69.

7. Hext PM, Pinto PJ, Gaskell BA. Methyl methacrylate in rat nasal epithelium: investigation of the time course of lesion development and recovery from short term vapor inhalation. Toxicology 2001;156:119-28.

8. Hochman N, Zalkind M. Hypersensitivity to methyl methacrylate: mode of treatment. J Prosthet Dent 1997;77:93-6.

9. Holland CJ, Kim KC, Malik MI, Ritter MA. A histologic and hemodynamic study of the toxic effects of monomeric methyl methacrylate. Clin Orthop Relat Res 1973;90:262-70.

10. Hurtt ME, Morgan KT, Working PK. Histopathology of acute toxic responses in selected tissues from rats exposed by inhalation to methyl bromide. Fundam Appl Toxicol 1987;9:352-65.

11. Lomax LG, Krivanek ND, Frame SR. Chronic inhalation toxicity and oncogenicity of methyl methacrylate in rats and hamsters. Food Chem Toxicol 1997;35:393-407.

12. Lönnroth EC, Shahnavaz H. Use of polymer materials in dental clinics, case study. Sweed Dent J 1997;21:149-59.

13. Mainwaring G, Foster JR, Lund V, Green T. Methyl methacrylate toxicity in rat nasal epithelium: studies of the mechanism of action and comparisons between species. Toxicology 2001;158:109-18. lead to functional injuries such as ciliary motility alterations with a decrease in the elimination of mucus and, eventually, pulmonary and tracheobronchial infections.

\section{CONCLUSION}

Air concentration of MMA in dental prosthesis laboratories and operating room facilities where it is handled shall not exceed 100 ppm, and exhausting systems should be used following Occupational Safety and Health rules. Moreover, governmental policies should warrant supervision and control of industrial and health facilities that use MMA-derived resins in their manufacturing procedures.

14. McLaughlin RE, Barkalow JA. Pulmonary toxicity of methyl methacrylate vapors: an environmental study. Arch Environ Health 1979;34(5):336-8.

15. Miller RR, Young JT, Kociba RJ, Keyes DG, Bodner $\mathrm{KM}$, Calhoun LL, et al. Chronic toxicity and oncogenicity bioassay of inhaled ethyl acrylate in Fischer 344 rats and B6C3F1 mice. Drug Chem Toxicol 1985;8:1-42.

16. Mizunuma K, Kawai T, Yasugi T, Horigushi S, Takeda S, Miyashita K, et al. Biological monitoring and possible health effects in workers occupationally exposed to methyl methacrylate. Int Arch Occup Environ Health 1993;65:227-32.

17. Olson MJ, Martin JL, LaRosa AC, Brady AN, Pohl LR. Immunohistochemical localization of carboxylesterase in the nasal mucosa of rats. J Histochem Cytochem 1993;41:307-11.

18. Reininghaus W, Koestner A, Klimisch HJ. Chronic toxicity and oncogenicity of inhaled methyl acrylate and nbutyl acrylate in Sprague-Dawley rats. Food Chem Toxicol 1991;29:329-40.

19. Solomon HM, McLaughlin JE, Swenson RE, Hagan JV, Wanner FJ, O'Hara GP, et al. Methyl methacrylate: inhalation developmental toxicity study in rats. Teratology 1993;48:115-25.

20. Tansy MF, Hohenleitner FJ, White DK, Oberly R, Landin WE, Kendal FM. Chronic biological effects of methyl methacrylate vapor. III. Histopathology, blood chemistries, and hepatic and ciliary function in the rat. Environ Res 1980;21:117-25.

21. Tansy MF, Kendall FM. Update on the toxicity of inhaled methyl methacrylate vapor. Drug Chem Toxicol 1979;2(4):315-30.

22. Wittczak T, Palczynski C, Szulc B, Gorski P. Bronchial asthma with inflammation of the nose mucous membrane induced by occupational exposure to methyl methacrylate in a dental technician. Med Pr 1996;47:259-66.

Received for publication on Nov 26, 2004

Sent for alterations on Jun 03, 2005

Accepted for publication on Jul 07, 2005 